\title{
Strengths and virtues and the development of resilience: A qualitative study in Suriname during a time of economic crisis
}

International Journal of Social Psychiatry 2018, Vol. 64(2) 180-188 (C) The Author(s) 2017 Reprints and permissions: sagepub.co.uk/journalsPermissions.nav DOI: 10.1 I77/00207640I7749624 journals.sagepub.com/home/isp (SAGE

\author{
Tom Hendriks' ${ }^{1}$, , Tobi Graafsma ${ }^{2}$, Aabidien Hassankhan', \\ Ernst Bohlmeijer ${ }^{3}$ and Joop de Jong ${ }^{4}$
}

\begin{abstract}
Background: Resilience can be described as the capacity to deal with adversity and traumatic events. The current economic situation in Suriname and its social economic consequences may demand a great amount of resilience for people living in Suriname. In this explorative study, we examined the relation between strengths and resilience among the three major ethnic groups in Suriname.

Method: Semi-structured interviews were conducted with 25 participants. We sought to gather viewpoints from community representatives, health care professionals and academic scholars about the personal resources used by people in Suriname to help them deal with the consequences of the current socio-economic crisis.

Results: We identified major five strengths that were associated with resilience: religiousness, hope, harmony, acceptance and perseverance. While these strengths contribute to the development of resilience, they can under certain circumstances have an ambiguous influence.

Conclusion: Our findings suggest that religiousness is the bedrock strength for the development of resilience in Suriname. We recommend that future positive psychological interventions in non-Western countries integrate positive activities with religious elements into program interventions to achieve a better cultural fit.
\end{abstract}

\section{Keywords}

Resilience, religiousness, positive psychology intervention, global mental health, strengths, positive mental health

\section{Background}

The Republic of Suriname is a country located in the northeast of South America. Suriname has an estimated population of 585,000, with almost half of its residents living in the capital Paramaribo. Suriname is a multi-ethnic society that consists of Afro-Surinamese (Creoles - 16\%; Maroons - 22\%), Hindustani (27\%), Javanese (14\%), mixed ethnicity (13\%), Amerindians (4\%), Chinese (1\%) and other (3\%) (Menke \& Sno, 2016). The three main religions in Suriname are Christianity (48.4\%), Hinduism $(22.3 \%)$ and Islam (13.9\%) (Algoe \& Schalkwijk, 2016). Suriname is currently classified by the World Bank as an upper-middle-income country; this classification was based on data prior to the crisis. After nearly a decade of strong economic growth, the economy entered a recession in 2015, which decreased the gross national product (GNP) in 2016 by 7\% (KNOEMA, 2016). Between September 2015 and May 2016, the Consumer Price Index (CPI) increased by $55 \%$ and the nominal currency of the Surinamese dollar depreciated by $98.8 \%$ against the US dollar (ECLAC, 2016). In June 2016, Suriname had the world's third highest inflation rate globally, just after Sudan and Venezuela (TradingEconomics, 2016).
The consequences of economic crises can affect the well-being of the population in a negative way; decrease and loss of income due to unemployment are two main risk factors affecting people's well-being. Symptoms of impaired well-being such as depression, anxiety, and reduced subjective well-being and self-esteem have often been reported (Fernández \& López-Calva, 2010; Glonti et al., 2015; Karanikolos et al., 2013; Ng, Agius, \& Zaman, 2013; Paul \& Moser, 2009; Zivin, Paczkowski, \& Galea, 2011). Increases in mortality rates are associated

\footnotetext{
'Anton de Kom Universiteit van Suriname, Paramaribo, Suriname 2Institute for Graduate Studies \& Research, Anton de Kom Universiteit van Suriname, Paramaribo, Suriname

${ }^{3}$ University of Twente, Enschede, The Netherlands

${ }^{4}$ Amsterdam Institute for Social Science Research, University of Amsterdam, Amsterdam, The Netherlands

Corresponding author:

Tom Hendriks, Faculty of Social Sciences, Department of Psychology, Anton de Kom Universiteit van Suriname (AdeKUS), Leysweg 86, P.O Box 9212 , Paramaribo, Suriname.

Email: tom.hendriks@uvs.edu.
} 
with economic crises, in both Western and developing countries, as well as deaths caused by homicide (Falagas, Vouloumanou, Mavros, \& Karageorgopoulos, 2009) and suicide (Piovani \& Aydiner-Avsar, 2015; Uutela, 2010; Van Hal, 2015; Veenhoven \& Hagenaars, 1989). The latter may be of great relevance, considering the high rates of suicide in Suriname in general and among the Hindustani population in the district of Nickerie in particular, where suicide is linked to poverty and unemployment (Graafsma, Kerkhof, Gibson, Badloe, \& Van de Beek, 2006; Graafsma, Westra, \& Kerkhof, 2016; van Spijker, Graafsma, Dullaart, \& Kerkhof, 2009).

Resilience is commonly understood as the capacity to deal effectively with stress and adversity, to adapt successfully to setbacks (Burton, Pakenham, \& Brown, 2010; Luthar, Cicchetti, \& Becker, 2000; Zautra, Hall, Murray, \& The Resilience Solutions Group 1, 2008), and to bounce back after negative emotional experiences (Tugade \& Fredrickson, 2004). Resilience is an active and multidimensional process, with three overarching characteristics, namely, individual, positive, dispositional attributions; family cohesion and support; and availability of external support systems (Garmezy, 1993; Masten \& Garmezy, 1985; Rutter, 1987; Werner, 1993). Socio-economic, cultural and historical factors also can influence resilience, at both individual and collective levels (Gunderson, 2010; Holling, 1973). Most research on resilience in low- and middle-income countries focuses on resilience following distress caused by severe adverse events such as war (Hall, Tol, Jordans, Bass, \& de Jong, 2014; Song, Tol, \& Jong, 2014; Tol, Song, \& Jordans, 2013), political violence (Hobfoll, Mancini, Hall, Canetti, \& Bonanno, 2011; Johnson et al., 2009; Lavi \& Slone, 2011; Tol et al., 2013), and natural disasters (Adger, Hughes, Folke, Carpenter, \& Rockström, 2005; Binder, Baker, Mayer, \& O’Donnell, 2014; Fu, Leoutsakos, \& Underwood, 2013). Much less is known about the effects of economic crises on mental health, especially in countries where large segments of the population are already living below, near or just above the poverty line, such as Suriname (Sobhie, Deboosere, \& Dekkers, 2015; van der Kooij et al., 2015). We argue that the current socio-economic crisis will demand a great amount of resilience of the Surinamese population in order to cope with the problems in their daily lives.

\section{Present study}

Findings of this study were used in the cultural adaptation process of a positive psychology intervention (PPI) that aims to increase resilience among healthy employees in Paramaribo, Suriname. In this study, we will focus on the specific positive and dispositional attributions of resilience, namely, strengths. One of the most often used activities in PPIs is identifying and using character strengths (Andrewes, Walker, \& O'Neill, 2014; Gander, Proyer, \&
Ruch, 2016; Mitchell, Stanimirovic, Klein, \& VellaBrodrick, 2009; Proyer, Gander, Wellenzohn, \& Ruch, 2015). We will classify strengths according to the Virtues in Action (VIA) Classification (Peterson \& Seligman, 2004). According to the VIA, virtues are considered core characteristics that have been valued by religious thinkers and philosophers throughout history, whereas character strengths are pathways to these virtues (Niemiec, 2012). The VIA mentions 24 universal character strengths (Duan, Bai, Tang, Siu, \& Ho, 2012; Park, Peterson, \& Seligman, 2004). Studies suggest that the development of character strengths is associated with increased resilience (Boe, 2016; Martínez-Martí \& Ruch, 2017; Shoshani \& Slone, 2016) and post-traumatic growth (Duan \& Guo, 2015; Peterson, Park, Pole, D'Andrea, \& Seligman, 2008). The main research question in this qualitative study is, 'What strengths associated with resilience are present in Suriname'?

\section{Method}

The consolidated criteria for reporting qualitative research (COREQ) were followed in the reporting of the findings (Tong, Sainsbury, \& Craig, 2007).

\section{Data collection}

Data were collected through semi-structured in-depth interviews that were conducted in the capital Paramaribo. The following aspects were explored: (1) participants' understanding of the concept of resilience, (2) the prevalence of strengths associated with resilience, and (3) the prevalence of specific strengths within the three main ethnic groups in Suriname. Table 1 shows an overview of the main questions that were asked during the interviews.

\section{Participants}

Candidates were recruited through purposive sampling (Palys, 2008) and snowball sampling (Atkinson \& Flint, 2001). We focused on community representatives, health care professionals, representatives from religious institutions, and academic scholars specialized in social sciences. We sought to gather viewpoints about the resources used by different communities to help them deal with the consequences of the current socio-economic crisis. In total, 39 people were approached via e-mail or telephone: 5 candidates did not react, 5 candidates refused participation for various reasons, and 2 interviews were canceled. In total, 27 participants were interviewed in 25 interview sessions. The first author interviewed all subjects in person at a location they preferred. During the interview, no other persons besides the participant and the researcher were present, except for two interviews that were conducted with two participants present, who answered the questions 
Table I. Overview of the main interview questions.

\begin{tabular}{|c|c|}
\hline Opening question & $\begin{array}{l}\text { 'What is your background and } \\
\text { working experience?' }\end{array}$ \\
\hline Introductory question & $\begin{array}{l}\text { 'What is your view on the } \\
\text { economic situation of the past } \\
\text { year?' }\end{array}$ \\
\hline Transition question & $\begin{array}{l}\text { "What does resilience mean to } \\
\text { you?' }\end{array}$ \\
\hline Key questions & $\begin{array}{l}\text { - 'What strengths can stimulate } \\
\text { resilience in Suriname?' } \\
\text { - 'What are typical strengths } \\
\text { among the Creole/Maroon/ } \\
\text { Hindustani/Javanese population } \\
\text { in Suriname?' }\end{array}$ \\
\hline Closing question & $\begin{array}{l}\text { 'How resilient are the Surinamese } \\
\text { people?' }\end{array}$ \\
\hline
\end{tabular}

Table 2. Demographics.

\begin{tabular}{lc}
\hline Male & 17 \\
Mean age (years) & 57 \\
Female & 8 \\
$\quad$ Age range (years) & $24-71$ \\
Total & 25 \\
\% college education & $8 \%$ \\
Focus of expertise & \\
General & 8 \\
Afro-Surinamese & \\
Hindustani & 7 \\
Javanese & 7 \\
Total & 3 \\
Occupation & 25 \\
Community representative & \\
Entrepreneur & 2 \\
Health care professional & 3 \\
Representative religious institution & 7 \\
Scholar & 5 \\
Representative governmental institution & 6 \\
Total & 2 \\
\hline
\end{tabular}

aCreoles and Maroons.

alternately. All interviews were audio-recorded and no field notes were made. Interviews were conducted in the Dutch language and lasted between 45 and 60 minutes. Two interviews were removed from the study due to technical reasons. In our analysis, we finally included 23 interviews with 25 participants. Table 2 shows the demographic characteristics of the participants.

\section{Interviews}

All interviews were conducted by the first author who received a formal academic training in conducting qualitative research. The interviewer was superficially acquainted through work with eight respondents prior to the interviews. Participants were informed of the general goal of the study (e.g. 'resilience in the light of the current economic crisis in Suriname') and its context (e.g. 'part of a dissertation on resilience and positive psychology in Suriname'). None of the participants received any financial compensation. Written informed consent was obtained from all participants.

\section{Data analysis}

All interviews were transcribed in Dutch and coded in English. All quotes were also translated into English. Data analysis was carried out with the use of ATLAS.ti 7.5.7. Coding went through a three-stage procedure. In the first stage, the first author performed an open coding analysis for all interviews. No coding tree was provided. In the second stage, axial coding was performed. In the third stage, selective coding was performed by the first and third author separately. Transcripts were not returned to the participants. After publication, all participants will receive a copy of the article.

\section{Results}

Most of our respondents had an individualistic understanding of the concept of resilience and referred to resilience as 'the capacity to deal with adversity ' or 'bouncing back after blows' and underline the importance of persistence and flexibility:

Resilience for me is the capacity to get up on your feet again. No matter what the outlook is, being able to continue and to make something or your life. (Respondent 20)

During the interviews, many different strengths were mentioned by the respondents, but we found five major strengths that may contribute to the development of resilience and that are applicable to all major ethnic groups. Religiousness, or spirituality, is the main strength and could be regarded as a bedrock for resilience. Hope, harmony, acceptance and perseverance are four strengths that are strongly associated with resilience. These four strengths all are perceived as related to religiousness.

\section{Religiousness}

According to our respondents, religiousness - independent from the world religion and philosophies they adhere to provides meaning, stability and a sense of security and offers comfort and solace. It can 'bring you to a peaceful state of mind'. Religiousness also strengthens social ties; in fact, it is regarded as the prime social network of many people in Suriname. Religiousness is also described as a source of empowerment, giving people the strength to both accept and improve their situation. The way religiousness is expressed may vary per denomination. Church attendance, daily prayer, and bible study are mentioned as 
religious activities practiced by most Afro-Surinamese Christians. Most church service focus on perfervid prayer. Some representatives of the congregations also underline the importance of carrying out Christian virtues such as kindness and charity. One respondent, a high representative of the Roman Catholic Church, underlines the importance of daily prayer and meditation:

Meditation is an individual process, we have few group meditations, people are encouraged to start the day with silence, in prayer. Not to start the day with all the noise, but rather seeking silence. (Respondent 4)

Attendance at mandirs (Hindu temple) and mosques, and daily prayer are also important for Hindus and Muslim, respectively. For some Hindus, meditation is a fundamental part of their religious practices. Yoga is also suggested as a way of increasing resilience, although two Hindustani respondents clearly point out that yoga consists of many steps including dnyana (meditation) and that the popular 'western' yoga styles that solely focus on asanas (physical postures) may not be very helpful in developing resilience. Orthodox Javanese Muslims practice salah (congregational prayer), which is seen as a form of meditation. One respondent explained that most Muslims in Suriname usually do not uphold to five daily moments of prayer for practical reasons, although many try to attend the salät aljumah, the congregational prayer on Friday after noon. A practice of orthodox Surinamese Muslims that was also mentioned by several respondents was ramadan (fasting), while unorthodox Muslims and Javanists practice a variety of rituals to appease the gods and spirits, for example, slametan (ritual meal offerings). One respondent explained how he believes religiousness can provide people with guidelines on how to deal with uncertainty. The various Holy Scriptures give illustrations of how this was done in ancient times by religious figures who act as positive role models. Respondents also associate religiousness with strengths such as love, kindness and gratitude. The display of these strengths can contribute to the development of resilience. While religiousness is considered a factor that generally increases resilience, several respondents also point out that religiousness may have an inhibiting influence on resilience. This will be discussed in the section on acceptance.

\section{Hope}

Despite the difficult economic situation, all respondents mentioned that they remain hopeful. They report a general positive future outlook among the people in Suriname. An example of hope and optimistic thinking is the often heard belief that Suriname is a country that has been blessed by God because Suriname has a fertile soil. Plants grow very quickly and people never have to worry about starvation.
None of the respondents has a negative long-term outlook on the economic situation; everyone believes that eventually better times in Suriname will come, since the country still has many untouched natural resources. Religious faith is a main source of hope. Respondents have the impression that most Surinamese have a strong faith in God, and the belief that He will take care of his people keeps the people in Suriname going. This was voiced by a representative of the Catholic Church in the following way:

We want to live and have to bear the things that are missing now, because there is a deep rooted faith within us, which we call hope and which keeps people on their feet. (Respondent 4)

\section{Harmony}

In general, there appears to be a strong sense of belongingness and connectedness in Suriname. All respondents underline the importance of unity and living in harmony with each other. Harmony is also strongly related to religiousness. Social relations that are forged during religious activities (attendance of church, temple or mosque services) are an important source for resilience according to our respondents. Although striving for harmony was found to be present in all ethnic groups, it appears to be a pivotal aspect of the Javanese community. Among the Javanese, there is a strong sense of solidarity and unity. Living in harmony is a central way of life, in Javanese language known as rukun. One expression of rukun is the gotong royong, a system of mutual cooperation where people save money collectively. For example, in this system, houses are built and paid for by the community. This striving for harmony also has a spiritual dimension:

Javanese believe that they have to live in harmony with their environment, to live harmony with the people around them. This is expressed through their kindness, humility, their acceptance and that fact that they do not want to cause any problems among each other [...] the Javanese believe that they always have to live in harmony, not only with their surroundings but also with the spiritual world. (Respondent 15)

The view that well-being is related to a harmonious relation with God and other deities or ancestral and nature spirits is present throughout all ethnic and religious groups in Suriname.

\section{Acceptance}

Another often reported strength that may contribute to resilience in Suriname is acceptance. Acceptance is closely related to harmony: if one is to avoid conflict with others, an accepting attitude may work effectively. Acceptance is also related to religiousness. In order to cope with daily 
stress, people simply accept the situation as it is, and surrender themselves to the situation, which is considered the will of God. Acceptance and religiousness can increase resilience according to our respondents. However, these factors can also decrease or inhibit the development of resilience. Acceptance and religiousness can lead to passivity, when people simply accept their situation as immutable or predestined:

Within the Evangelic Brotherhood Church it is called 'saka fasi' (literally a fixed matter). A sort of humility: as a human you are nothing. Whatever happens to you, you have to take it. (Respondent 2)

In the Surinamese language we have a saying 'Libi yu srefi gi gron tapu' which literally means to surrender yourself to the world. That means having no resilience. (Respondent 1)

In some cases, religious beliefs can lead to magical ways of thinking, which is even stimulated in some religious congregations. One respondent, an Afro-Surinamese anthropologist, referred to the term 'cargo cult' which he believes is particularly strong among the Creoles and Maroons in Suriname:

This is the point of view that people believe that everything will be better at some point, that better times will come. The ancestors and spirits will return and bring you wealth and prosperity. As a way of speaking, one day you wake up and there is a bag of one million SRD on your table or beside your bed. (Respondent 17)

The view that religion may hinder the development of resilience was mainly voiced by respondents who had a neutral or skeptical attitude toward religion. The representatives of the religious communities we have spoken to clearly advocate a pro-active interpretation of the teachings of the scriptures.

\section{Perseverance}

As a people, the Surinamese see themselves as persevering. Many respondents place the current crisis in a historical perspective as many people have gone through times that were much harsher than the current situation:

After all the misery we have gone through, we remain optimistic, we know that every cloud has a silver lining. We have had slavery, we have had contract work. We have had colonial structures. We have had authoritarian education. We have had 'revolutions. We have had economic downfalls. But you will not get us down. (Respondent 1)

Perseverance is also related to religiousness; faith in God is what keeps many people going, as previously was indicated in the section on hope. Among the Hindustani population, perseverance is reflected in their workings ethics, which are said to be strong. This can be associated with the Hindu concept of swadharma: the personal duties. Their sense of duty is what may lie behind perseverance, according to one respondent:

The drive why people actually do things is the sense of duty. You have to do your swadharma; your own duties. That is a strong concept in Hinduism. (Respondent 14)

\section{Discussion}

Most of our respondents had an individualistic understanding of the term resilience. Resilience is mostly viewed as the capacity to deal with adversity. In our study, we focused on resilience in the light of the current economic crisis. Resilience pertains mostly to the capacity of dealing with financial adversities that have a profound impact on the emotional, social, spiritual well-being of people in Suriname. We noted that physical, mental, occupational and environmental/political aspects of resilience were not addressed by most of our respondents.

In our study, we identified five major strengths that are associated with resilience: religiousness, hope, harmony, acceptance and perseverance. Religiousness is the bedrock component, with hope, harmony, acceptance and perseverance as components that are interconnected with religiousness. Religiousness offers solace and a sense of security. It also provides a source of empowerment and meaning. Religious practices differ per creed. Daily prayer and devotional service at home, reading religious scriptures and meditation are activities that seem to contribute to emotional and psychological well-being in all religious. Attendance services in churches, mandirs and mosques also strengthen social ties and contribute to social wellbeing of people in Suriname.

Our findings about the role of religion in relation to mental health are consistent with findings from previous studies, suggesting that religious and spiritual activities serve as protective factors for mental health, as they can be powerful sources of happiness, meaning, hope and harmony (AbdAleati, Zaharim, \& Mydin, 2014; BrewerSmyth \& Koenig, 2014; Ivtzan, Chan, Gardner, \& Prashar, 2013; Koenig, 2012; Lun \& Bond, 2013; Park et al., 2013; Rizvi \& Hossain, 2016). Religiousness can also contribute to a decrease in indicators of negative mental health, including depression, anxiety, stress, substance abuse, mortality rate and suicidality (Gonçalves, Lucchetti, Menezes, \& Vallada, 2015; Koenig, 2012; Lucchetti, Lucchetti, \& Koenig, 2011; Wu, Wang, \& Jia, 2015). Morton, Lee, and Martin (2016) identified three mechanisms that may explain the relationship between religiousness and mental health: religions institutions often promote healthier lifestyles, attendance to religious service increases social support, and the participation in religious rituals leads to the experience of more positive emotions. Although in our study the first mechanism was not brought 
to light, the other two mechanisms did appear prominently. First, our findings suggest that religiousness has a strong social support function in Suriname. According to our respondents, being with family members and friends is very important and religious institutions play a central role in maintaining and expanding the social network of people. This is applicable to all ethnic groups. All throughout Paramaribo, there are churches, temples and mosques that function as places of social gatherings. The different religions in Suriname appear to live in harmony with each other, and people of different creeds coexist peacefully and interact in daily life. The literature discussing the positive relation between religiousness and social support dates back to Durkheim's work in the beginning of the 20th century. Durkheim underlined the social function of religion and argued that religion is a source of solidarity and social cohesion (Durkheim \& Bellah, 1973; Moñivas, 2007). More recent studies suggest that a strong sense of belonging to a religious congregation is associated with better health (Krause \& Wulff, 2005), increases meaning in life (Lambert et al., 2013), and acts as a protective factor against loneliness and depression (Baskin, Wampold, Quintana, \& Enright, 2010). Thwarted belongingness may increase the risk of suicide (Silva, Ribeiro, \& Joiner, 2015).

However, religiousness also has an ambivalent role, meaning that it can actually inhibit the development the resilience in Suriname, particularly when it is combined with two other strengths. Religiousness in combination with acceptance and hope can result in a passive attitude. People will simply accept their disadvantaged situation as something that is the will of God. The hope that things will someday simply change for the better can reinforce this passivity. Church attendance and other religious rituals then become a form of escapism. While this may be an effective short-term coping strategy for stress, it can inhibit the development of resilience in the long run. Two respondents underlined the importance of active agency, in relation to religiousness and spirituality. They argue that religiousness is a strong stimulant for the development or resilience, when people act to improve their situation.

In our analysis, we set out to classify strengths according to the VIA list. Almost all character strengths of the VIA list were mentioned by the respondents somewhere during the interviews, but religiousness, hope and perseverance were mentioned most frequently. In addition to these three major strengths, we found strengths (or possibly virtues) that are not acknowledged in the VIA categorization, namely, harmony and acceptance. We define harmony (unity) as a virtue that entails striving to live harmoniously with the social, natural and/or spiritual environment. Kim et al. (2010) argued that harmony is a virtue comprising a number of strengths, including modesty/ humility, prudence, forgiveness, love, kindness, gratitude and hope. Acceptance refers to the ability to accept changing situation quickly and the flexibility to be able to adapt quickly to different situations. We find it remarkable that acceptance is not (yet) included in the VIA list, since it is a core virtue in all eastern religions and philosophies. Acceptance even plays an essential part of psychological therapies that have been accepted in Western countries, such as mindfulness-based therapies (Bohlmeijer, Prenger, Taal, \& Cuijpers, 2010; Demarzo, Montero-Marn, Cuijpers, \& Garcia-Campayo, 2015; Hayes, Follette, \& Linehan, 2004) and Acceptance and Commitment therapy (Fledderus, Bohlmeijer, Pieterse, \& Schreurs, 2012; Fledderus, Bohlmeijer, Smit, \& Westerhof, 2010). Due to these findings, we suggest that using the VIA in the context of a collectivistic country such as Suriname, and possibly other collectivistic countries, may be somewhat limited.

\section{Programmatic implications}

In terms of implications for PPIs in non-Western countries, we first recommend that PPIs include strength and virtues - activities that are culturally adapted. This can be done, for example, by organizing focus groups with community representatives to identify the most prevalent strengths among the target group. Also, prevalent religious practices can be integrated into PPIs, for example, by incorporating tales from the various Holy Scriptures and prayer or meditation exercises into the program modules. An example of such an approach is described in a study by Saeedi, Nasab, Zadeh, and Ebrahimi (2015) who conducted a PPI with an Islamic approach that included Islamic comments on the program. We suggest that when integrating religious elements into a program, this should be done in combination with making participants aware of active strengths such as perseverance, leadership and teamwork. In addition, we suggest incorporating goal-setting activities to avoid that the PPI will stimulate passivity. Second, we advise using different or additional instruments than the VIA list when inventorying strengths in non-Western communities, such as the strength-based approach by Linley that identifies 60 strength profiles that may be a better fit with non-Western cultural values such as 'connector', 'rapport builder' and 'service' (Linley, Willars, Biswas-Deiner, Garcea, \& Stairs, 2010).

\section{Limitations}

This study provided data from a small group of respondents with particular fields of expertise. Since the sample does not reflect the entire Suriname population, it is not possible to extrapolate the findings to the general Suriname population. One limitation of the study is that people from lower socio-economic strata who have been hit hardest by the economic crisis have not been interviewed. Another limitation of the study was that all respondents we interviewed lived and worked in Suriname's capital Paramaribo. 
We did not interview people who lived outside of Paramaribo, for example, in the districts Nickerie or Marowijne. Caution is warranted when making causal inferences on the basis of the data from this study. Simply because participants report that some factors are important for resilience, it does not mean that factors actually generate resilience. Furthermore, we recommend further quantitative research on the prevalence of strengths among the various ethic cultural groups in Suriname.

\section{Conclusion}

In conclusion, this qualitative study illustrates how religiousness may be considered the bedrock factor for resilience in Suriname. It is interconnected with other strengths, including hope and perseverance. Religiousness, however, can also inhibit the development of resilience, when it is focused on a passive attitude. For non-Western countries, we recommend that future positive psychology programs take into account the pivotal role of religiousness as a potential resilience-enhancing factor. This could be done by integrating religious rituals into program exercises and by choosing program modules that are in line with religious and cultural values in a particular study population. Such programs should also promote active agency.

\section{Funding}

The author(s) received no financial support for the research, authorship and/or publication of this article.

\section{ORCID iD}

Tom Hendriks (iD http://orcid.org/0000-0002-5220-0640

\section{References}

AbdAleati, N. S., Zaharim, N. M., \& Mydin, Y. O. (2014). Religiousness and mental health: Systematic review study. Journal of Religion and Health, 55, 1929-1937.

Adger, W. N., Hughes, T. P., Folke, C., Carpenter, S. R., \& Rockström, J. (2005). Social-ecological resilience to coastal disasters. Science, 309, 1036-1039.

Algoe, K., \& Schalkwijk, J. (2016). Religion in Suriname: Demgraphic changes between 1971 and 2012. In J. Menke (Ed.), Mosiac of the Surinamese People (pp. 112-132). Paramaribo, Suriname: Institute of Graduate Studies and Research.

Andrewes, H. E., Walker, V., \& O’Neill, B. (2014). Exploring the use of positive psychology interventions in brain injury survivors with challenging behaviour. Brain Injury, 28 , 965-971.

Atkinson, R., \& Flint, J. (2001). Accessing hidden and hardto-reach populations: Snowball research strategies. Social Research Update, 33(1), 1-4.

Baskin, T. W., Wampold, B. E., Quintana, S. M., \& Enright, R. D. (2010). Belongingness as a protective factor against loneliness and potential depression in a multicultural middle school. The Counseling Psychologist, 38, 626-651.
Binder, S. B., Baker, C. K., Mayer, J., \& O’Donnell, C. R. (2014). Resilience and recovery in American Sāmoa: A case study of the 2009 South Pacific tsunami. Journal of Community Psychology, 42, 799-822.

Boe, O. (2016). Building resilience: The role of character strengths in the selection and education of military leaders. International Journal of Emergency Mental Health and Human Resilience, 17, 714-716.

Bohlmeijer, E., Prenger, R., Taal, E., \& Cuijpers, P. (2010). The effects of mindfulness-based stress reduction therapy on mental health of adults with a chronic medical disease: A meta-analysis. Journal of Psychosomatic Research, 68, 539-544.

Brewer-Smyth, K., \& Koenig, H. G. (2014). Could spirituality and religion promote stress resilience in survivors of childhood trauma? Issues in Mental Health Nursing, 35, 251256.

Burton, N. W., Pakenham, K. I., \& Brown, W. J. (2010). Feasibility and effectiveness of psychosocial resilience training: A pilot study of the READY program. Psychology, Health \& Medicine, 15, 266-277.

Demarzo, M., Montero-Marn, J., Cuijpers, P., \& GarciaCampayo, J. (2015). The efficacy of mindfulness-based interventions in primary care: A meta-analytic review. Annals of Family Medicine, 13, 573-582.

Duan, W. J., Bai, Y., Tang, X. Q., Siu, P. Y., \& Ho, S. M. (2012). Virtues and positive mental health. Mental Health, 38(2), $1-8$.

Duan, W., \& Guo, P. (2015). Association between virtues and posttraumatic growth: Preliminary evidence from a Chinese community sample after earthquakes. PeerJ, 3, e883.

Durkheim, E., \& Bellah, R. N. (1973). Émile Durkheim on Morality and Society Selected Writings. Chicago: University of Chicago Press.

ECLAC. (2016). Economic Survey of Latin America and the Caribbean. New York, NY: United Nations.

Falagas, M., Vouloumanou, E., Mavros, M., \& Karageorgopoulos, D. (2009). Economic crises and mortality: A review of the literature. International Journal of Clinical Practice, 63, $1128-1135$.

Fernández, A., \& López-Calva, L. F. (2010). Transitory shocks, permanent effects: Impact of the economic crisis on the wellbeing of households in Latin America and the Caribbean. Estudios Económicos, 25, 3-35.

Fledderus, M., Bohlmeijer, E., Pieterse, M., \& Schreurs, K. (2012). Acceptance and commitment therapy as guided selfhelp for psychological distress and positive mental health: A randomized controlled trial. Psychological Medicine, 42, 485-495.

Fledderus, M., Bohlmeijer, E. T., Smit, F., \& Westerhof, G. J. (2010). Mental health promotion as a new goal in public mental health care: A randomized controlled trial of an intervention enhancing psychological flexibility. American Journal of Public Health, 100, 2372-2372.

Fu, C., Leoutsakos, J. M., \& Underwood, C. (2013). Moderating effects of a postdisaster intervention on risk and resilience factors associated with posttraumatic stress disorder in Chinese children. Journal of Traumatic Stress, 26, 663-670.

Gander, F., Proyer, R. T., \& Ruch, W. (2016). Positive psychology interventions addressing pleasure, engagement, 
meaning, positive relationships, and accomplishment increase well-being and ameliorate depressive symptoms: A randomized, placebo-controlled online study. Frontiers in Psychology, 7, 686.

Garmezy, N. (1993). Children in poverty: Resilience despite risk. Psychiatry, 56, 127-136.

Glonti, K., Gordeev, V. S., Goryakin, Y., Reeves, A., Stuckler, D., McKee, M., \& Roberts, B. (2015). A systematic review on health resilience to economic crises. PLOS ONE, 10(4), e0123117.

Gonçalves, J., Lucchetti, G., Menezes, P., \& Vallada, H. (2015). Religious and spiritual interventions in mental health care: A systematic review and meta-analysis of randomized controlled clinical trials. Psychological Medicine, 45, 29372949.

Graafsma, T., Kerkhof, A., Gibson, D., Badloe, R., \& Van de Beek, L. (2006). High rates of suicide and attempted suicide using pesticides in Nickerie, Suriname, South America. Crisis, 27(2), 77-81.

Graafsma, T., Westra, K., \& Kerkhof, A. (2016). Suicide and attempted suicide in Suriname: The case of Nickerie. Academic Journal of Suriname, 7, 628-642.

Gunderson, L. (2010). Ecological and human community resilience in response to natural disasters. Ecology and Society, 15(2), Article 18.

Hall, B. J., Tol, W. A., Jordans, M. J., Bass, J., \& de Jong, J. T. (2014). Understanding resilience in armed conflict: Social resources and mental health of children in Burundi. Social Science \& Medicine, 114, 121-128.

Hayes, S. C., Follette, V. M., \& Linehan, M. (2004). Mindfulness and acceptance: Expanding the cognitive-behavioral tradition. New York, NY: Guilford Press.

Hobfoll, S. E., Mancini, A. D., Hall, B. J., Canetti, D., \& Bonanno, G. A. (2011). The limits of resilience: Distress following chronic political violence among Palestinians. Social Science \& Medicine, 72, 1400-1408.

Holling, C. S. (1973). Resilience and stability of ecological systems. Annual Review of Ecology and Systematics, 4, 1-23.

Ivtzan, I., Chan, C. P., Gardner, H. E., \& Prashar, K. (2013). Linking religion and spirituality with psychological wellbeing: Examining self-actualisation, meaning in life, and personal growth initiative. Journal of Religion and Health, 52, 915-929.

Johnson, R. J., Canetti, D., Palmieri, P. A., Galea, S., Varley, J., \& Hobfoll, S. E. (2009). A prospective study of risk and resilience factors associated with posttraumatic stress symptoms and depression symptoms among Jews and Arabs exposed to repeated acts of terrorism in Israel. Psychological Trauma: Theory, Research, Practice, and Policy, 1, 291-311.

Karanikolos, M., Mladovsky, P., Cylus, J., Thomson, S., Basu, S., Stuckler, D., \& McKee, M. (2013). Financial crisis, austerity, and health in Europe. The Lancet, 381, 1323-1331.

Kim, J. H., Berven, N., Chan, F., Gonzalez, R., Miller, D., \& Keck, P. (2010). Virtues in relation to subjective well-being for people with chronic illness and disability. Journal of Asia Pacific Counseling, 1(1), 61-76.

KNOEMA. (2016). World data atlas: Suriname. Retrieved from https://knoema.com/atlas/Suriname/topics/Economy/ National-Accounts-Gross-Domestic-Product/GDP-growth
Koenig, H. G. (2012). Religion, spirituality, and health: The research and clinical implications. ISRN Psychiatry, 2012, 33. doi: http://dx.doi.org/10.5402/2012/278730.

Krause, N., \& Wulff, K. M. (2005). RESEARCH: Church-based social ties, a sense of belonging in a congregation, and physical health status. The International Journal for the Psychology of Religion, 15(1), 73-93.

Lambert, N. M., Stillman, T. F., Hicks, J. A., Kamble, S., Baumeister, R. F., \& Fincham, F. D. (2013). To belong is to matter: Sense of belonging enhances meaning in life. Personality and Social Psychology Bulletin, 39, 1418-1427.

Lavi, I., \& Slone, M. (2011). Resilience and political violence: A cross-cultural study of moderating effects among Jewishand Arab-Israeli youth. Youth \& Society, 43, 845-872.

Linley, A., Willars, J., Biswas-Deiner, R., Garcea, N., \& Stairs, M. (2010). The strengths book: Be confident, be successful and enjoy better relationships by realising the best of you. Coventry, UK: Capp Press.

Lucchetti, G., Lucchetti, A. L., \& Koenig, H. G. (2011). Impact of spirituality/religiosity on mortality: Comparison with other health interventions. Explore: The Journal of Science and Healing, 7, 234-238.

Lun, M.-C., \& Bond, M. H. (2013). Examining the relation of religion and spirituality to subjective well-being across national cultures. Psychology of Religion and Spirituality, 5, 304-315.

Luthar, S. S., Cicchetti, D., \& Becker, B. (2000). The construct of resilience: A critical evaluation and guidelines for future work. Child Development, 71, 543-562.

Martínez-Martí, M. L., \& Ruch, W. (2017). Character strengths predict resilience over and above positive affect, self-efficacy, optimism, social support, self-esteem, and life satisfaction. The Journal of Positive Psychology, 12, 110-119.

Masten, A. S., \& Garmezy, N. (1985). Risk, vulnerability, and protective factors in developmental psychopathology. In B. B. Lahey \& A. E. Kazdin (Eds.), Advances in clinical child psychology (pp. 1-52). Springer US.

Menke, J., \& Sno, I. (2016). Race and ethnicity in census of Suriname. In J. Menke (Ed.), Mosiac of the Surinamese people. (pp. 76-94). Paramaribo, Suriname: Institute of Graduate Studies and Research.

Mitchell, J., Stanimirovic, R., Klein, B., \& Vella-Brodrick, D. (2009). A randomised controlled trial of a self-guided internet intervention promoting wellbeing. Computers in Human Behavior, 25, 749-760.

Moñivas, J. R. (2007). Science and religion in the sociology of Émile Durkheim. European Journal of Science and Theology, 3(1), 17-30.

Morton, K. R., Lee, J. W., \& Martin, L. R. (2016). Pathways from religion to health: Mediation by psychosocial and lifestyle mechanisms. Psychology of Religion and Spirituality, 9(1), 106-117.

Ng, K. H., Agius, M., \& Zaman, R. (2013). The global economic crisis: Effects on mental health and what can be done. Journal of the Royal Society of Medicine, 106, 211-214.

Niemiec, R. M. (2012). VIA character strengths: Research and practice (The first 10 years). In H. H. Knoop \& A. D. Fave (Eds.), Well-being and cultures: Perspectives on positive psychology (pp. 11-30). New York, NY: Springer. 
Palys, T. (2008). Purposive sampling. In L. M. Given (Ed.), The $S A G E$ encyclopedia of qualitative research methods (Vol. 2, pp. 697-698). Los Angeles, CA: SAGE.

Park, N., Peterson, C., \& Seligman, M. E. (2004). Strengths of character and well-being. Journal of Social and Clinical Psychology, 23, 603-619.

Park, N. S., Lee, B. S., Sun, F., Klemmack, D. L., Roff, L. L., \& Koenig, H. G. (2013). Typologies of religiousness/spirituality: Implications for health and well-being. Journal of Religion and Health, 52, 828-839.

Paul, K. I., \& Moser, K. (2009). Unemployment impairs mental health: Meta-analyses. Journal of Vocational Behavior, 74, 264-282.

Peterson, C., Park, N., Pole, N., D’Andrea, W., \& Seligman, M. E. (2008). Strengths of character and posttraumatic growth. Journal of Traumatic Stress, 21, 214-217.

Peterson, C., \& Seligman, M. E. P. (2004). Character strengths and virtues: A handbook and classification. Oxford, UK: Oxford University Press.

Piovani, C., \& Aydiner-Avsar, N. (2015). The 2008/09 economic crisis: The impact on psychological well-being in the USA. Forum for Social Economics, 44(1), 18-45.

Proyer, R. T., Gander, F., Wellenzohn, S., \& Ruch, W. (2015). Strengths-based positive psychology interventions: A randomized placebo-controlled online trial on long-term effects for a signature strengths- vs. a lesser strengths-intervention. Frontiers in Psychology, 6, 456.

Rizvi, M. A. K., \& Hossain, M. Z. (2016). Relationship between religious belief and happiness: A systematic literature review. Journal of Religion and Health, 56(5), 1561-1582.

Rutter, M. (1987). Psychosocial resilience and protective mechanisms. American Journal of Orthopsychiatry, 57, 316-331.

Saeedi, H., Nasab, S. H. M., Zadeh, A. M., \& Ebrahimi, H. A. (2015). The effectiveness of positive psychology interventions with Islamic approach on quality of life in females with multiple sclerosis. Biomedical and Pharmacology Journal, 8, 965-970.

Shoshani, A., \& Slone, M. (2016). The resilience function of character strengths in the face of war and protracted conflict. Frontiers in Psychology, 6: 2006. doi: 10.3389/ fpsyg.2015.02006.

Silva, C., Ribeiro, J. D., \& Joiner, T. E. (2015). Mental disorders and thwarted belongingness, perceived burdensomeness, and acquired capability for suicide. Psychiatry Research, 226, 316-327.

Sobhie, R., Deboosere, P., \& Dekkers, G. (2015). Hoe arm is Suriname? The Academic Journal of Suriname, 6, $574-591$.
Song, S. J., Tol, W., \& Jong, J. (2014). Indero: Intergenerational trauma and resilience between Burundian former child soldiers and their children. Family Process, 53, 239-251.

Tol, W. A., Song, S., \& Jordans, M. J. (2013). Annual research review: Resilience and mental health in children and adolescents living in areas of armed conflict-A systematic review of findings in low-and middle-income countries. Journal of Child Psychology and Psychiatry, 54, 445-460.

Tong, A., Sainsbury, P., \& Craig, J. (2007). Consolidated criteria for reporting qualitative research (COREQ): A 32-item checklist for interviews and focus groups. International Journal for Quality in Health Care, 19, 349-357.

TradingEconomics (Producer). (2016). Country information Suriname. Retrieved from http://www.tradingeconomics. com/suriname/inflation-cpi

Tugade, M. M., \& Fredrickson, B. L. (2004). Resilient individuals use positive emotions to bounce back from negative emotional experiences. Journal of Personality and Social Psychology, 86, 320-333.

Uutela, A. (2010). Economic crisis and mental health. Current Opinion in Psychiatry, 23, 127-130.

van der Kooij, I. W., Nieuwendam, J., Bipat, S., Boer, F., Lindauer, R. J., \& Graafsma, T. L. (2015). A national study on the prevalence of child abuse and neglect in Suriname. Child Abuse \& Neglect, 47, 153-161.

Van Hal, G. (2015). The true cost of the economic crisis on psychological well-being: A review. Psychology Research and Behavior Management, 8, 17-25.

van Spijker, B. A., Graafsma, T., Dullaart, H., \& Kerkhof, A. J. (2009). Impulsive but fatal self-poisoning with pesticides among South Asians in Nickerie, Suriname: An exploratory autopsy study. Crisis, 30, 102-105.

Veenhoven, R., \& Hagenaars, A. (1989). Did the crisis really hurt? Effects of the 1980-1982 economic recession on satisfaction, mental health and mortality. Rotterdam, The Netherlands: Universitaire Pers.

Werner, E. E. (1993). Risk, resilience and recovery: Perspectives from the Kauai longitudinal study. Development and Psychopathology, 5, 503-515.

Wu, A., Wang, J.Y., \& Jia, C.X. (2015). Religion and completed suicide: A meta-analysis. PLoS ONE, 10(6), e0131715.

Zautra, A. J., Hall, J. S., Murray, K. E., \& The Resilience Solutions Group 1. (2008). Resilience: A new integrative approach to health and mental health research. Health Psychology Review, 2(1), 41-64.

Zivin, K., Paczkowski, M., \& Galea, S. (2011). Economic downturns and population mental health: Research findings, gaps, challenges and priorities. Psychological Medicine, 41, 1343-1348. 